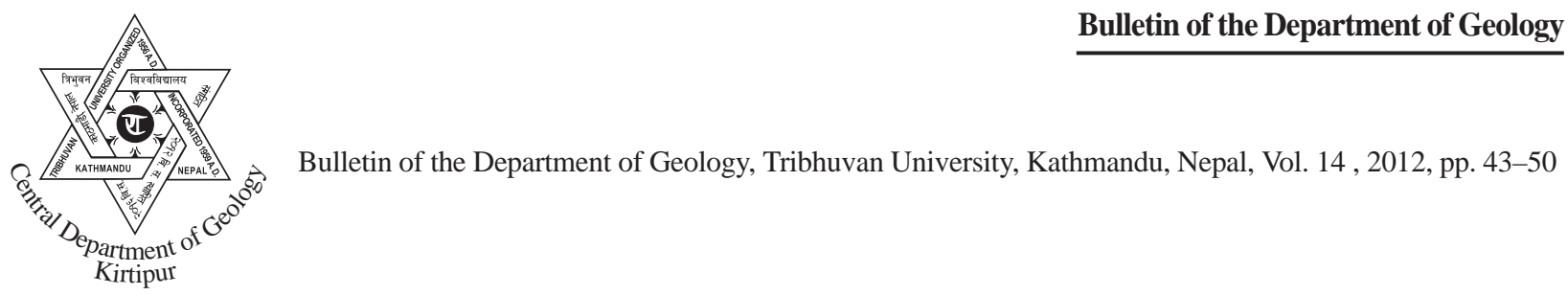

\title{
Quality and economic aspects of roofing slates in theTharpu area, Tanahu
}

\author{
*Naba Raj Neupane ${ }^{1}$ and Lalu Prasad Paudel ${ }^{2}$ \\ ${ }^{1}$ Department of Environmental Science, Amrit Science College, Tribhuvan University, Kathmandu, Nepal \\ ${ }^{2}$ Central Department of Geology, Tribhuvan University, Kathmandu, Nepal
}

\begin{abstract}
A preliminary study on the occurrence, quality and economic aspects of the slates was carried in the slate deposits of the Tharpu area, west Nepal Lesser Himalaya. The area is covered by the Nourpul Formation, Dhading Dolomite and the Benghat Slates of the Lower Nawakot Group forming a broad synclinal structure. Three deposits of slates were identified in the area at Seratar (Nourpul Formation), Phapardanda (Nourpul Formation) and the Chipliswara (Benighat Slate). Samples from all three deposits were analyzed by petrographic, X-ray diffraction and Physico-chemical testing methods. The study shows that the slates are well foliated, splitable into thin and smooth slabs, and physico-chemically close to the ASTM and IS standard values. The quantity of slate is good enough for mining economically.
\end{abstract}

\section{INTRODUCTION}

Slate is a fine-grained, foliated metamorphic rock created as a result of the alteration of shale or mudstone by low-grade regional metamorphism. It displays fairly perfect natural cleavage and readily splitable into thin and smooth sheets. Slaty cleavage results from the parallel orientation of flaky minerals. Due to its thin splitting properties, slates are mostly used for roofing purposes. Slates can also be used for paving, cladding, flagging, wainscoting, trimming, stair treads, chalkboards, pool and laboratory tables etc. (Carr, 1994), because of its durability and attractive appearance.

Slate is used in Nepal for roofing and cladding of home yards for several years. There have been only a very few studies on slates in Nepal in the past. The report by UN (1976) described some slate deposits in the Lesser Himalaya Region at various locations. Sharma (1960), UN (1977), UN (1993) have described occurrence of very good slate at Bandipur area, Tanahu. Slate occurrences have been also reported

\footnotetext{
*Corresponding author:

E-mail address: nneupane@gmail.com
}

from Singchyang Garhi (Udayapur), Gairimudi (Kavre), Chautara area (Sidhupalchok), Bigu (Dolakha), Gaighat (Tanahu), Kelodighat (Syangja), Ranipauwa (Nuwakot), Gajuri (Dhading), etc. DMG (2004) has indicated 31 locations for slate occurrences in different parts of the country. Detailed exploration of the slate occurrences to identify quality, quantity and possibility of mining are still lacking.

The Tharpu area (Fig. 1) of Tanahu district (8406'30"E-8411'30"E longitudes and 2758 '36"N-2801'30"N latitudes) is well-known for slate mining in western Nepal. A preliminary study on the occurrence, quality and economic aspects of the slates was carried out in three quarry sites of the Tharpu area. The study shows that the quality of slates in the area is close to ASTM (American Standard for Testing Materials) standard and economically viable.

\section{GEOLOGICAL SETTING OF THE SLATE DEPOSITS}

The Lesser Himalaya with mostly Precambrian to Early Paleozoic unfossiliferous rocks, in places covered by metamorphic and crystalline thrust sheets, is bounded by the Main Boundary Thrust (MBT) in 


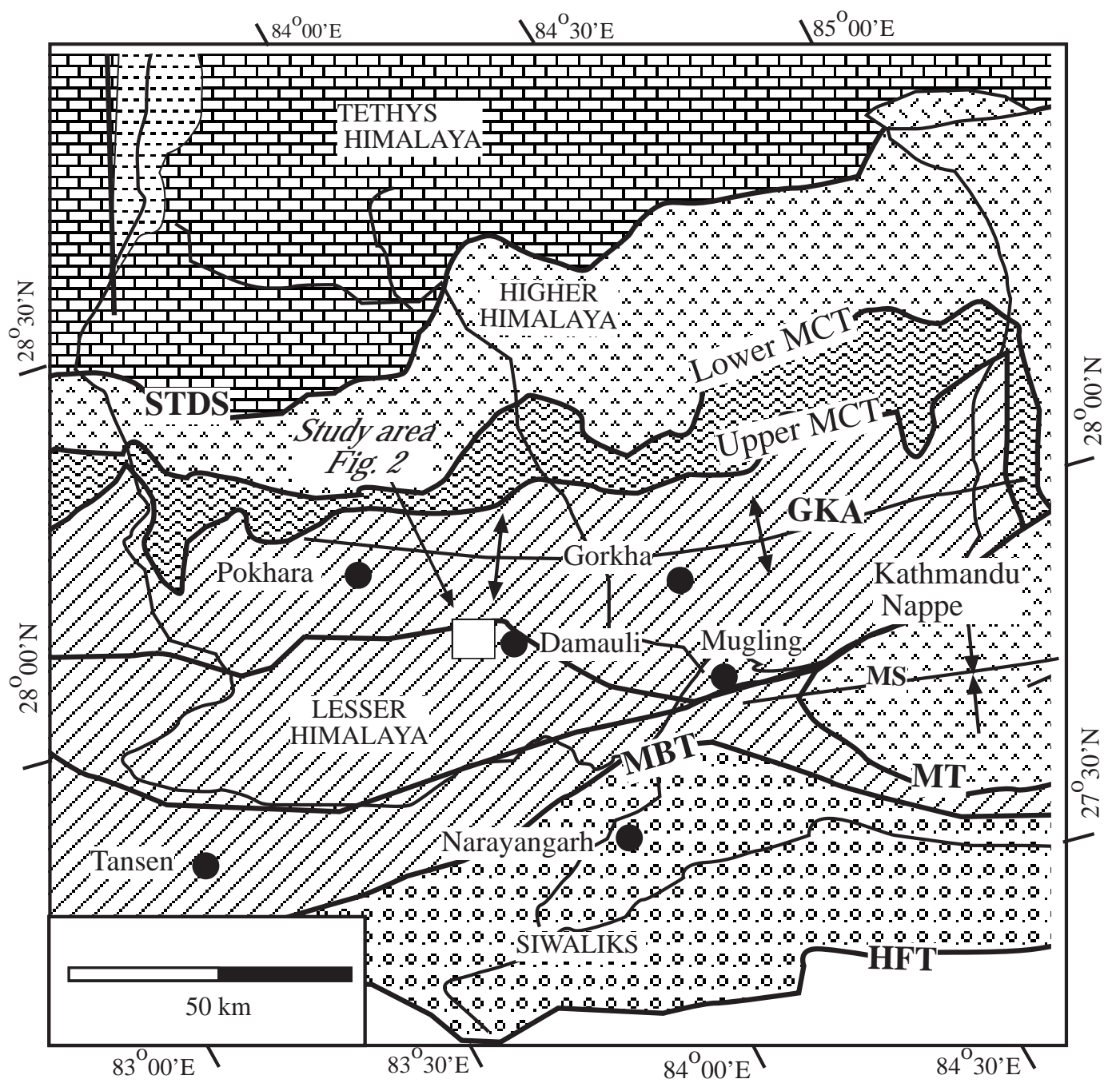

Fig. 1 Tectonic setting of central Nepal showing the location of the study area (modified from Paudel and Arita, 2000).

the south and Main Central Thrust (MCT) in the north. The Higher Himalayan Proterozoic crystalline rocks are thrust over the Lesser Himalaya along the MCT. Present study area lies in the Midland zone of the Lesser Himalaya. The study area is covered by the Nourpul Formation, Dhading Dolomite and Benighat Slates of the Lower Nawakot Group, Nawakot Complex (Stöckiln, 1980). The rocks are intensely folded producing a major WNW-ESE trending syncline and two small anticlines (Fig. 2). The axis of the syncline passes from The Tharpu village.

Slate deposits were observed at three places namely Seratar, Phapardanda and Chipliswara (Fig. 2). Slates of different sizes and shapes are being presently mined and used for roofing from those areas (Fig. 3). The slates at Seratar and Phapardanda belong to the
Nourpul Formation. The typical stratigraphic sequence of the Nourpul Formation observed at Seratar is given in Fig. 4 (a). It is composed of alternating bands of grey slate and grey, pink and green quartzites of about $1100 \mathrm{~m}$ thickness. Slates are being quarried from the lower part of the Formation. The slates at Chipliswara belong to the Benighat Slate. The Benighat Slate is composed of alternating bands of grey slate, black slate and grey quartzite (Fig. $4 \mathrm{~b}$ ). The Benighat Slate is about $3000 \mathrm{~m}$ in the study area. Slate is being mined there from the lower part of the sequence.

\section{METHODS OF QUALITY ASSESSMENT}

During the field study, 15 specimens of slate were collected from each area, i.e., Seratar, Phapardada 


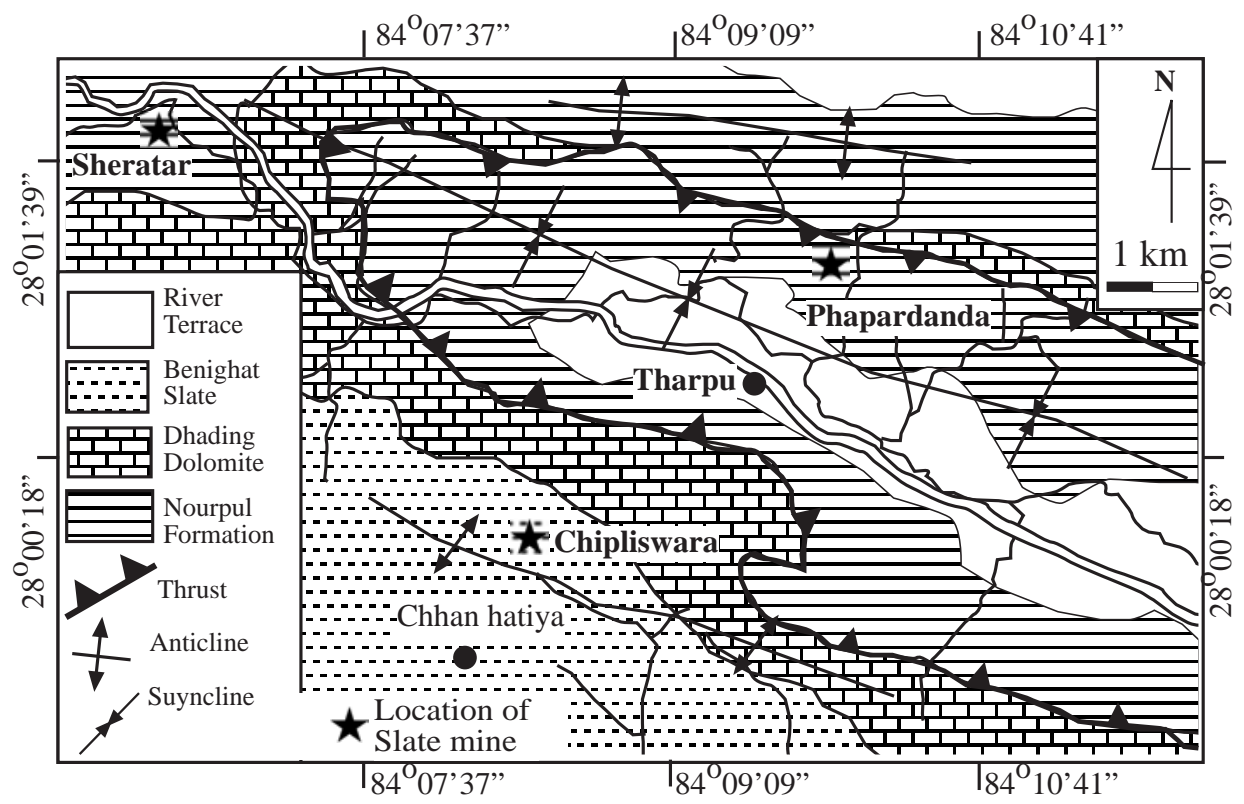

Fig. 2 Geological map of the study area showing the location of slate deposits.
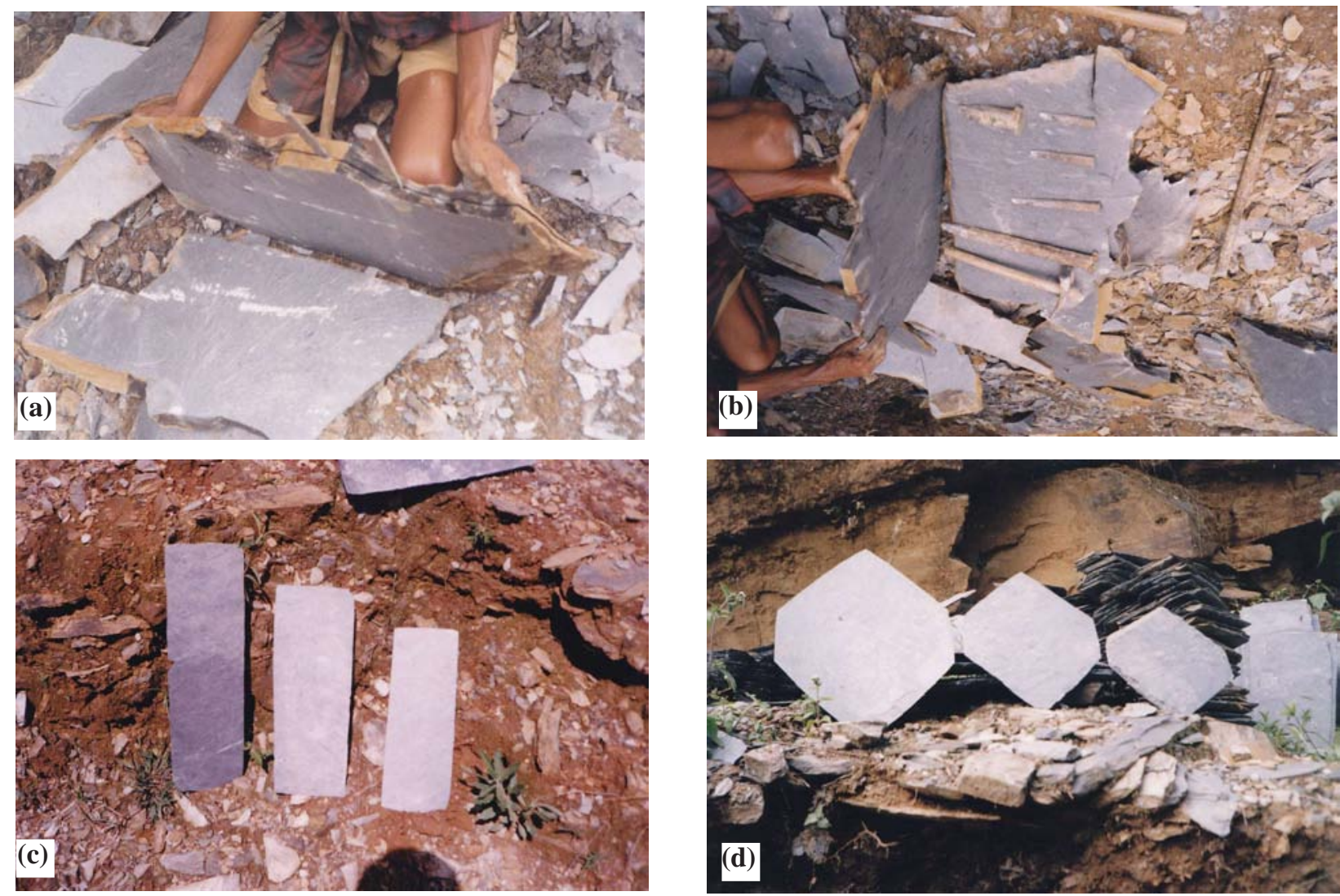

Fig. 3 Field photographs showing mining activities at different quarry sites in the study area. (a) Photograph showing slate splitting techniques, Seratar, Tanahu. (b) Photograph showing traditional tools used in splitting of slate at Seratar, Tanahu. (c) Rectangular slates of different sizes ready for sale. Jethi: $45 \times 22$ to $15 \mathrm{~cm}$ (left), Mahili: $35 \times 22$ to $15 \mathrm{~cm}$ (middle) and Kanchi:28x22 to $15 \mathrm{~cm}$ (right); (d) Hexagonal slates of different sizes ready for sale. Jethi:19x12 cm (left), Mahili:18x18 cm (middle) and Nanu:15x6 cm (right). 


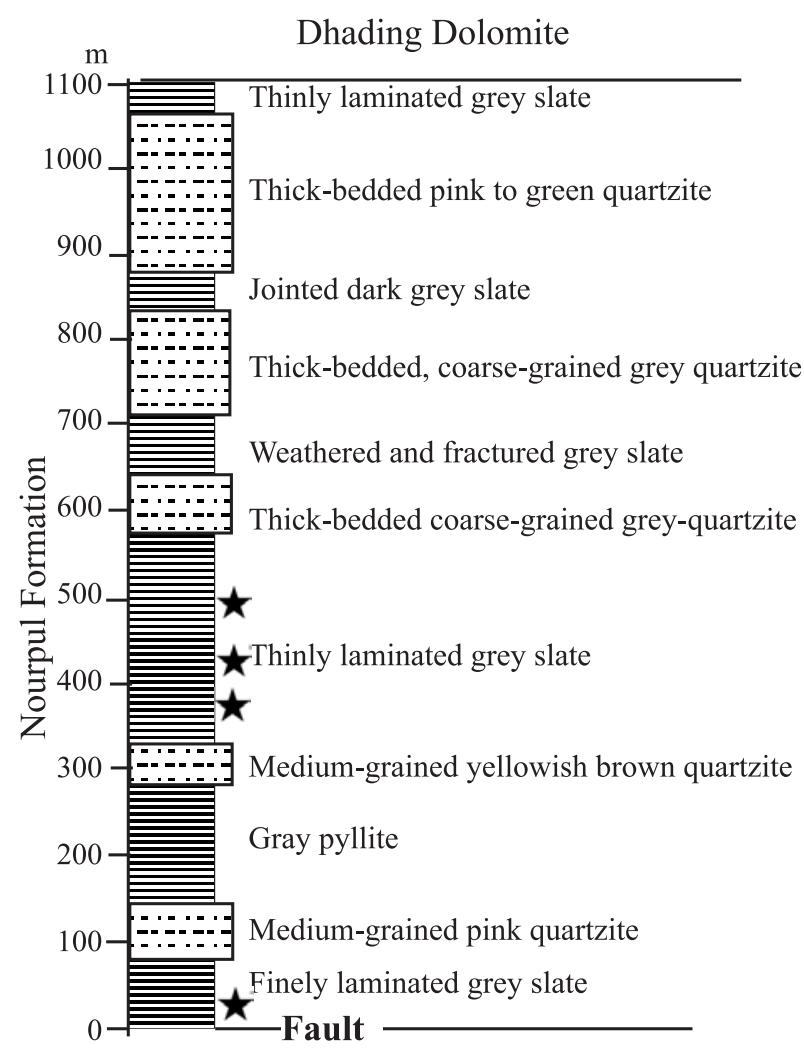

(a)

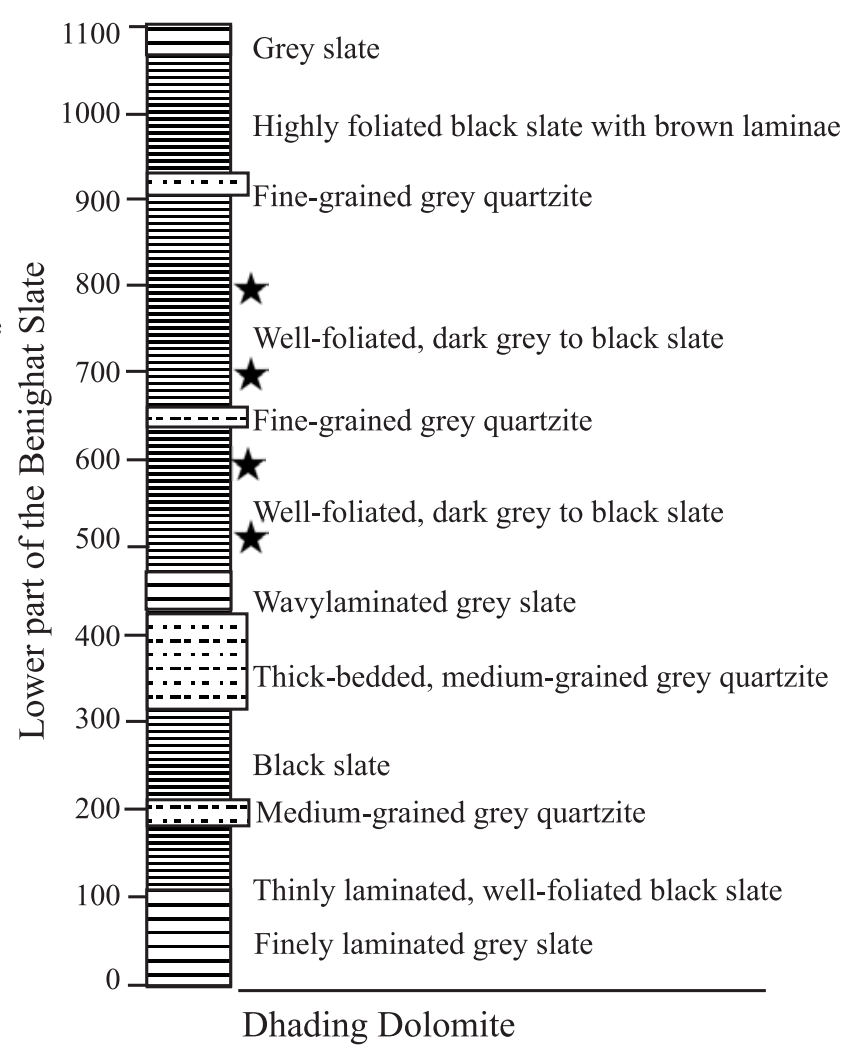

(b)

Fig. 4 (a) Columnar section of the Nourpul Formation showing the stratigraphic position of slate mining at Seratar and (b) the same at Chipliswara. Stars indicate stratigraphic position of quarry sites.

and Chipliswara. Testing of the samples was performed with three different methods as follows.

\section{Petrological study}

\section{X-ray diffraction study}

\section{Physico-chemical test}

Petrological study was carried out to check the mineralogy and perfectness of foliation in the slate. Crystallinity of white mica was measured with the help of X-ray Diffractometer to check the degree of metamorphism. Flexure, water absorption, weathering resistance, abrasion, sulphuric acid immersion and wetting and drying tests were carried out to check the physical and chemical strength of slate. Permeability, sulphuric acid immersion and wetting and drying tests were followed as described in Indian Standard (IS6250-1981). The other tests were as suggested in ASTM standard (1996). The procedures are given in Neupane (2003).

\section{RESULTS}

\section{Petrographic study}

Seratar

The slates from Seratar are composed of phyllosilicates (muscovite and chlorite; $45 \%$ ), quartz ( $\sim 20 \%$ recrystallized, $\sim 15 \%$ detrital), rutile $(\sim 5 \%)$, and unknown $(\sim 15 \%)$. Thickness of phyllosilicate layers ranges from $0.01-0.04 \mathrm{~mm}$. Size of quartz domain attains maximum thickness of $0.05 \mathrm{~mm}$. Most of the quartz and phyllosilicates are elongated forming nematoblastic texture (Fig. 5a). Slaty cleavage is developed by preferred orientation of pyllosilicates and elongated quartz. Cleavage planes are straight and continuous all over the slide.

\section{Phapardada}

The slates from Phapardanda comprise white mica ( $\sim 30 \%$ ), chlorite $(\sim 20 \%)$, quartz ( $15 \%$ detrital, $\sim 10 \%$ 

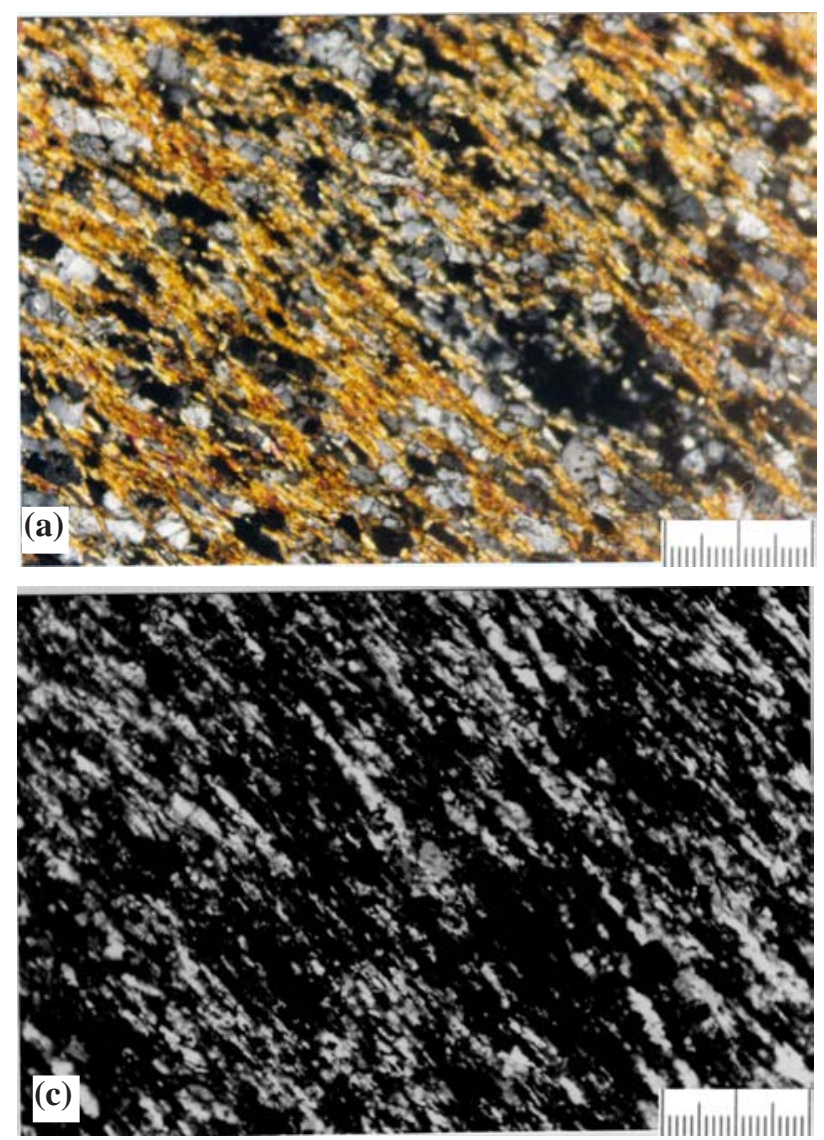

recrystallize), rutile $(\sim 10 \%)$, feldspar $(\sim 5 \%)$ and unknown $(\sim 10 \%)$. Thickness of quartz domain ranges from 0.02 to $0.1 \mathrm{~mm}$ and that of phyllosilicate domain ranges from 0.05 to $0.2 \mathrm{~mm}$. Quartz grains are fractured with imperfect layering (Fig. 5b). Chlorite and white mica layers show aggregates of lenticular domains, which are recognized throughout the thin section.

\section{Chipliswara}

The slates from Chipliswara are composed of phyllosilicate $(\sim 40 \%)$, quartz ( $10 \%$ recrystallized, $\sim 35 \%$ detrital), rutile $(\sim 5 \%)$ and unknown $(\sim 10 \%)$. Thickness of quartz domains vary from 0.05 to 0.15 $\mathrm{mm}$. Similarly, the thickness of phyllosilicate domains varies from 0.015 to $0.02 \mathrm{~mm}$ (Fig. 5c). The angular outlines of the detrital quartz grain are still preserved even though clay minerals are completely recrystallized to chlorite and micas.

\section{X-ray diffraction analysis}

$\mathrm{X}$-ray diffraction analysis was carried out to

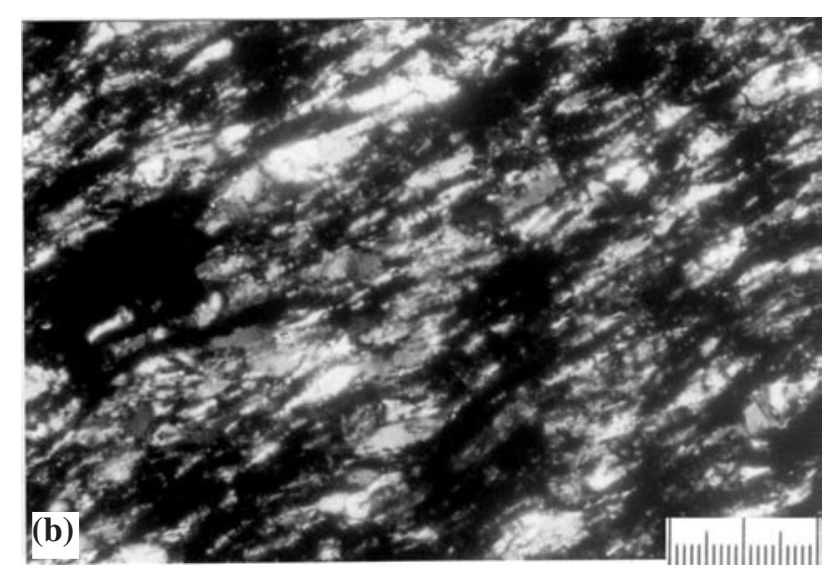

Fig. 5 (a) Photomicrograph of slate from Seratar, (b) Phapardanda and (c) Chipliswara. Scale 1 small division= $0.01 \mathrm{~mm}$.

measure the illite crystallinity (IC), which is an important indicator of degree of metamorphism in slates (Kübler, 1967). Three samples from each site were prepared for illite crystallinity measurement. The procedures for sample preparation and IC measurement are described in Paudel (2002). The average KI value for Benighat Slate samples is 0.10 (epizone) and for Nourpul Formation samples is 0.11 (epizone). These KI values indicate the temperature of metamorphism of about $375^{\circ} \mathrm{C}$ for all the samples calculated using the method of Underwood et al. (1993), i.e., KI = 1.197-0.0029 (TC).

\section{Physico-chemical tests}

The results of physico-chemical tests are summarized in Table 1. The modulus of rupture values in the tested samples range from 35.2 to 50.6 (average $=41.5 \pm 8.1$ ) $\mathrm{MPa}$ along the grain and 37.3 to 59.8 (Average $=46.3 \pm 11.9$ ) $\mathrm{MPa}$ across the grain. The modulus of elasticity ranges from 1055.4 to 2974 (average $=1808.7 \pm 1023.5) \mathrm{MPa}$. The water absorption by weight ranges from 0.8 to 1.2 (average $=0.9 \pm 0.2$ ). 
Table 1: Results of physico-chemical test for durability of slate

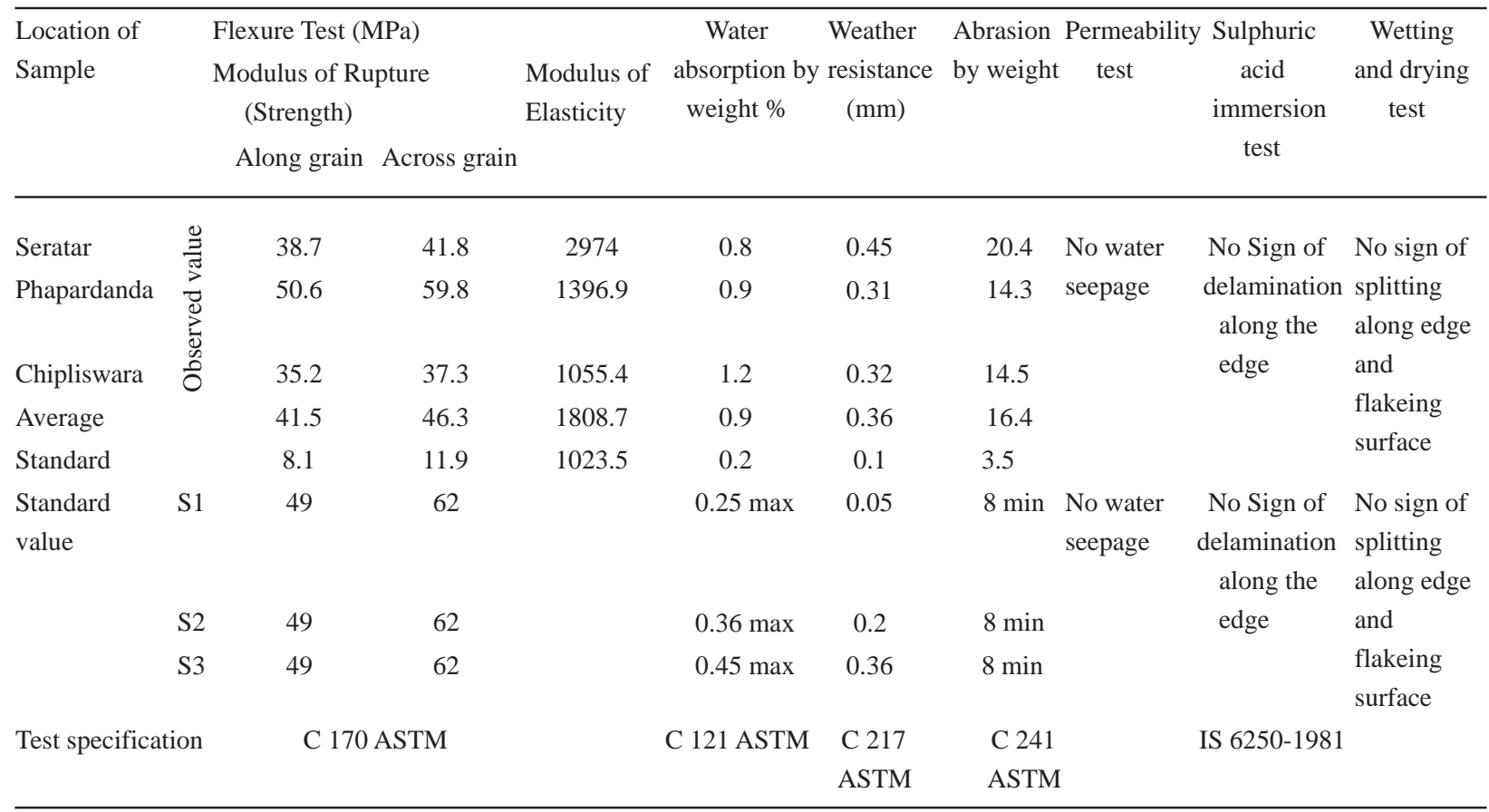

Similarly, weather resistance ranges from 0.3 to 0.45 $\mathrm{mm}$ (average $=0.36 \pm 0.1 \mathrm{~mm})$. Abrasion by weight ranges from 14.3 to 20.4 (average $=16.4 \pm 3.5$ ). The samples do not show any sign of water seepage, reaction with sulphuric acid and no sign of splitting along edge and flaking surface.

\section{DISCUSSIONS}

\section{Quality of slate}

Petrographic studies show that the minerals in slates are well-recrystallized and well-foliated under greenschist facies of metamorphism. The phyllosiclicate domains are relatively thin and continuous whereas quartz domains are relatively thick $(0.01$ to $0.4 \mathrm{~mm})$. These petrographic characteristics indicate possibility of good splitting properties with thin sheets and smooth surfaces. Well recrystallization of quartz and interlocking grains exhibit good physical strength of the slate. This has been actually justified by the slabs of slates mined in the area (Fig. 3) and the physical tests given in Table 1.

The physico-chemical test values for the present samples have been compared with that of standard values in Table 1. The specimens from Seratar and
Phapardanda (Nourpul Formation) gave better quality of water absorption and modulus of elasticity than samples from the Chipliswara (Benighat Slate). The samples from Chipliswara show relatively good weather resistance and abrasion by weight compared to the samples from other areas. In general, the physico-chemical test values are close to the American Standard of Testing Materials (ASTM) and Indian Standards (IS).

\section{Economic Aspects}

Although the slates from the study area are of good quality, various other factors affect the economic value of the deposit. Quantity, environmental factors, mining technology, skilled and semi-skilled manpower, haulage, and available market place are some of the key factors affecting the Cost-Benefit analysis. For profitable business the benefits and cost ratio should always be greater than one.

Present slate deposits are accessible by graveled road connected to highway. As the local people are working in the quarry for long time, they are welltrained. Presently, a person can produce about 170 pieces of different slate (Jethi: $45 \times 20 \mathrm{~cm}^{2}$, Mahili: $35 \times 20 \mathrm{~cm}^{2}$, Kanchi: $28 \times 20 \mathrm{~cm}^{2}$ and Sanukanchi: $25 \times 20 \mathrm{~cm}^{2}$ ) in a day. Table 2 shows the analysis of 
Table 2: Benefit cost ratio of one-day production produced by a skilled person

\begin{tabular}{|c|c|}
\hline Production (No. of pieces) & 127 \\
\hline Mining cost & Rs. 950 \\
\hline Royalty (Rs. 20/ton) & Rs. 4.2 \\
\hline $\begin{array}{l}\text { Transportation (nearest market, } \\
\text { i.e., Pokhara) }\end{array}$ & Rs. 2500 \\
\hline Total cost (TC) & Rs. 3454.2 \\
\hline Total Revenue (TR) & Rs. 4250 \\
\hline Net Revenue & Rs. 795.8 \\
\hline Benefit cost ratio $\mathrm{B} / \mathrm{C}$ or $\mathrm{TR} / \mathrm{TC}$ & 1.23 \\
\hline
\end{tabular}

benefit cost ratio of the production by one skilled labor. The analysis predicts that the slate business is profitable by $\mathrm{B} / \mathrm{C}$ ratio $=1.23$.

Reserve and cost benefit analysis of the slate deposit at Chipliswara was carried out by Neupane (2003). The total probable quantity of slate in the site has been estimated to be about $3113281 \mathrm{~m}^{3}$ based on topo-geological survey and conventional crosssectional method. The stripping ratio [recoverable reserve/(waste+overburden)] of slate is 1.3. The deposit is sufficient for 173 years of mining at 74.5 $\mathrm{m}^{3} /$ day production capacity for working days of 250 per year by 100 miners at cost benefit ratio of 1.22. It will generate 3.0 million rupees of revenue (considering $12.75 / \mathrm{m}^{3}$ of royalty rate) and 0.8 million rupees of benefit at the present market value.

\section{CONCLUSIONS}

The slate deposits of the study area belong to the Benighat Slate and Nourpul Formation of the Lesser Himalaya. Petrographic study shows that they are well-foliated, recrystallized and characterized by thick phyllosilicate domains. Illite crystallinity shows that they were metamorphosed under greenschist facies condition with temperature of about $375^{\circ} \mathrm{C}$. Physicochemical tests show that they are close to ASTM and IS standards. The slate deposits are economically profitable considering present economic factors such as wage rates, market price and royalty rates.

\section{ACKNOWLEDGEMENTS}

We are grateful to the Central Department of Geology, Kirtipur and the Institute of Engineering, Pulchowk for providing laboratory facilities. Bureau of Standards and Metrology, Government of Nepal provided procedures for slate testing. We thank Uttam Bol Shrestha for providing literatures on dimension stones.

\section{REFERENCES}

ASTM, 1996. Soil and Rock, Building stone, Sec. 4 Vol. 4.08, Annual Book by American Society for Testing and Materials (ASTM) Standards, ASTM, Philadelphia, Pennsylvania, USA.

Carr, D. D. (1994). Industrial Minerals and Rock. 6th edition, Society for mining, Metallurgy and Exploration, Inc. Litteleton, Colorado.

DMG (2004). Mineral Resources of Nepal, published by the Department of Mines and Geology, Government of Nepal, $154 \mathrm{p}$.

IS: 6250 (1981). Indian Standard, Specification for roofing slate tiles, Indian Standard Institution, New Delhi.

Kübler, B. (1967). La dristalliniteÂ de l'illite et les zones tout fait supérieures du métamorphisme, Etages Tectoniques A la Baconniére, Neuchatel (Suisse), pp. 105-121.

Neupane, N. (2003). Quality assessment, reserve estimation and economic analysis of roofing slate in the Tharpu area, Tanahu district, west central Lesser Himalaya. M. Sc. dissertation submitted to the Central Department of Geology, Tribhuvan University, Nepal, $72 \mathrm{p}$.

Paudel, L. P. (2002). Illite crystallinity evidence for polyphase metamorphism and inverted thermal structure in the Lesser Himalaya of central Nepal (Tansen-Pokhara section). Bulletin of the Department of Geology, Tribhuvan University, V. 8, pp.1-14.

Paudel, L. P. and Arita, K. (2000). Tectonic and polymetamorphic history of the Lesser Himalaya in central Nepal. Journal of Asian Earth Sciences, v. 18, pp. 561-584, 2000.

Sharma, C. K (1960). Bandipur Slate deposits, DMG (unpub.), $9 \mathrm{p}$.

Stöcklin, J. (1980). Geology of Nepal and its regional Frame. Journal of the Geological Society of the London, v. 137, pp. 1-34.

Underwood, M.B., Laughland, M.M., Kang, S.M. (1993). A comparison among organic and inorganic indicators of diagenesis and low-temperature metamorphism, Tertiary Shimanto Belt, Shikoku, Japan. Geological Society of Japan Special Paper v. 273, pp. 45-61. 
N. R. Neupane and L. P. Paudel Bulletin of the Department of Geology, Vol. 14, 2011, pp. 43-50

United Nations, 1993. Atlas of mineral resources of the ESCAP region volume 9, geology and mineral resources of Nepal, UN/ESCAP, $107 \mathrm{p}$.

United Nations, 1976. The Development Potential of Dimension Stone, E. 76, II.A4, New York, 64 p. 